\title{
NATURAL RUBBER LATEX AND GUM ARABIC: A COMPARISON OF PHYSICO-CHEMICAL PROPERTIES
}

\author{
Lawrence Chukwuka Edomwonyi-Otu \\ Department of Chemical and Petroleum Engineering, Delta State University, Abraka, Nigeria. 334101
}

Email: uceclce@ucl.ac.uk,+2349099265536

\begin{abstract}
The present investigation deals with the determination of the physio-chemical properties of two commercial grade samples of local gums (Gum Arabic and Natural Rubber Latex (NRL)). The results revealed that the gum samples have high melting point that indicate thermal stability at room and moderate temperatures. The gum samples have about $95 \%$ carbohydrate content and a corresponding high internal energy and can serve as a source of energy. The rheology of the samples revealed shear-thickening characteristics with gum Arabic being thixotropic and pseudoplastic in nature while NRL was observed to be anti-thixotropic and rheopectic. Further results from the moisture absorption, contact angle and Fourier Transform Infrared Radioscopy (FTIR) analyses gave better insight into their hydroscopic behaviors. Gum Arabic has excellent water absorption capacity with less wettability as it consists mainly of more water-soluble compounds in comparison to Natural Rubber Latex. These insights from the study will enhance wider application of the gums with increased value-addition to the gums and the communities where they (can) thrive.
\end{abstract}

Keywords: gums; density; wettability; latex; gum Arabic; rheology

\section{INTRODUCTION}

Rubber latex and gum Arabic are gums which are water-soluble polysaccharides that are extractable land plants. They also contain some protein materials and are important agro-forestry resources in Nigeria (Yusuf, 2011). They can enhance the viscosity and gelling ability with their dispersions. Hence, the key qualities of the gums are their water solubility and high viscosity in aqueous dispersions. Guar gums are harvested from the stems and branches of the resource gum trees as dry exudates. Hydrophobic affinity chromatography showed that gum Arabic is made up of three major constituents namely; Arabinogalactan (AG), Arabinogalactan protein (AGP), and Glycoprotein (GP). The highly branched polysaccharide part of the gum represents about $90 \%$ of the total gum (Taha, et al, 2012). 
The complex nature of plant gums is based on the fact that each gum sample possess a special combination of sugar (monosaccharide unit) to form the polysaccharide. The most widely distributed sugar in plant gums are mannose, galactose, ramose, fructose, xylose and the sugar acid. They contain residual amount of fats, protein, metabolites, metal ions, crude fibers etc. Raw materials of plant origin have proven to be relatively non-toxic, bio-compatible, readily accessible, economical and cost effective. In this regard plant gums are used for wide industrial applications such as in the cosmetic, pharmaceuticals and in food industries (Reichman, 1993).

The prediction of the properties of these gums is a challenge because of their heterogeneity in addition to their complex nature. Hence, their industrial applications require reliable information that can only be obtained from proper characterization of samples. The physicochemical properties of a compound are the measurable physical and chemical characteristics by which the compound may interact with other systems. This characteristic collectively determines the quality, applicability or the end-use of the compound. In plant gums, these properties are directly influenced by the botanical type, age, location, nature of the growing soil and the climatic condition around the resource gum tree (Yusuf, 2011). Physicochemical characterization of gums therefore is an essential step towards establishing suitability for industrial application. This focus of this study is to determine the physio-chemical properties and characterization of natural lubber latex and guar gum as found in Nigeria. This is to enable us gain insight into their quality, applicability and end use in industries. Information about these properties are scanty in open literature. Such physio-chemical properties include the ash content, moisture content, moisture absorption, $\mathrm{pH}$, percentage lipid content, crude protein, carbohydrate content, and functional groups among others. Just as other natural resources have been studied (Abdallah, Edomwonyi-Otu, Yusuf, \& Baba, 2019; Edomwonyi-Otu \& Aderemi, 2010; Edomwonyi-Otu, Aderemi, Ahmed, Coville, \& Maaza, 
2013; Gimba \& Edomwonyi-Otu, 2020) The knowledge of their properties and applications for value addition and enhance the economic wellbeing of the communities where they thrive.

\section{EXPERIMENTAL}

\section{PREPARATION OF SAMPLES}

\section{Gum Arabic}

The crude sample consisted of mixture of large and small nodules mixed with the bark and other organic debris obtained from the bark of wounded Acacia Senegal plant and Frankincense plant. Hand picking method was used to separate the neat gum lumps from debris and other constituents. The lumps were then spread out under room temperature to dry. The dried sample was then ground into powder and $150 \mathrm{~g}$ of the sample weighed inside an empty dried weighed bucket by using the weighing balance (CWS Series with accuracy of $\pm 0.05 \%$ FS). The sample was added to a $200 \mathrm{ml}$ hot boiled water to dissolve the sample. Proper protective equipment was worn for safety purposes. The gum-water system was properly stirred to ensure complete dissolution of the gum in water. It was thereafter stored in a tight container at room temperature for 48 hours and stirred at 6 hours intervals to ensure a perfect dissolution, proper hydration and adsorption (Edomwonyi-Otu, Chinaud, \& Angeli, 2015). The dissolved solution was centrifuged (strained) to remove air bubbles and any insoluble residual lumps through a muslin cloth (mesh) in a jug and sieved into another container. The undissolved lumps of the sample were transferred into a crucible and placed in the oven (Gallenkamp TM OV-420) at a temperature of $90^{\circ} \mathrm{C}$ to dissolve further by gentle heating. The dissolved solution was then mixed, weighed and filtered using a mesh to separate the clear gum solution from dirt. The weight of the clear solution after filtration was measured. Formalin was added to the gum Arabic clear solution to prevent deterioration, and then stored (Yusuf, 2011). 


\section{Natural Rubber Latex}

$300 \mathrm{ml}$ of the crude rubber latex gum was tapped from the stem of rubber latex plant (hevea brasiliensis) using a v-shaped knife. The raw latex was then centrifuged to remove water molecules. Ammonia solution was then added to the solution to prevent deterioration (Hassan \& Singh, 2014)

\section{ANALYSING THE PHYSIO-CHEMICAL PROPERTIES OF THE GUM SAMPLES}

\section{Density and Specific Gravity Measurement}

Density and specific gravity analysis of $1 \% \mathrm{w} / \mathrm{v}$ of the test samples was carried out using a density bottle and following methods described elsewhere (Edomwonyi-Otu, 2019). The weight of the empty bottle was measured (W) using CWS Series weighing balance (accuracy of $\pm 0.05 \%$ FS) and then weight of the bottle with $70 \mathrm{ml}$ of the test samples of gum acacia solution and rubber latex gum respectively as $\left(\mathrm{W}_{1}\right)$. The difference was taken to obtain the actual weight of the liquid solution; the weight was divided by the volume to obtain the density as shown in equation (1)

Density of the gum samples $=\frac{W_{1}-W}{V} \times 100$

Where; $\mathrm{W}_{1}$ is the weight of bottle and the test sample of the gum solution, $\mathrm{W}$ is the weight of the empty bottle and $\mathrm{V}$ is the volume of the gum samples.

\section{Ash Content and Moisture Content}

The analysis of moisture and ash content was determined using 2 clean crucibles of known weight dried in an oven at $102^{\circ} \mathrm{C}$ for 30 minutes. $10 \mathrm{~g}$ of both samples were placed in the crucibles and the put into an oven (Gallenkamp TM OV-420) at a regulated temperature of $125^{\circ} \mathrm{C}$ for 6 hours. The Moisture content was taken as percentage ratio of the change in the weight to the original sample weight. The dry weight of the ash was taken, and the ash was ignited at $550^{\circ} \mathrm{C}$ in a muffle furnace 
for 1 hour, content was cooled in a desiccator for 30 minutes and weighed. The ash content was taken as the percentage loss in weight after ignition to that of the original sample. Equation (2) and (3) gives the temperature for calculating $\%$ moisture and \% ash content respectively.

$$
\% \text { Moisture content }=\frac{W_{1}-W_{2}}{W_{1}} \times 100
$$

Where; $\mathrm{W}_{1}$ is the original weight of the gum samples, $\mathrm{W}_{2}$ is weight of the gum samples after drying

$$
\% \text { Ash content }=\frac{C_{1}-C_{2}}{C_{1}} \times 100
$$

Where; $\mathrm{C}_{1}$ is the dry weight of ash, $\mathrm{C}_{2}$ is the weight of ash after ignition

\section{Moisture Adsorption of the Dried Gum Samples}

The gum samples were dried in an oven (Gallenkamp TM OV-420), then spread in a thin layer in a weighing dish and kept at $22^{\circ} \mathrm{C}$ and $42 \%$ relative humidity. The weight was measured at different times.

\section{$\mathrm{pH}$ Determination}

The $\mathrm{pH}$ of $1 \% \mathrm{w} / \mathrm{v}$ of the gum samples solution was determined with a microprocessor-based $\mathrm{pH}$ meter (Jenway 3510) which was set to neutral at room temperature and the electrode was immersed into the solution.

\section{Viscosity and Thixotropy Measurement}

The viscosity and thixotropy of the samples were measured using a rheometer (Ostwald viscometer VS135, $\pm 1.0 \%$ accuracy). At room temperature of $25^{\circ} \mathrm{C}$, the gum solution at a known concentration was poured from the bottle container into a $75 \mathrm{ml}$ beaker and the temperature measured using a thermometer. The speed of the viscometer was then adjusted to $0.5 \mathrm{rpm}$ and the viscometer reading measured and recorded (I. A. Dosumu, Edomwonyi-Otu, Yusuf, \& Abubakar, 2020). The procedure was repeated for different speeds and the readings taken. 


\section{Melting Point}

A melting point capillary was used for this purpose. A tiny sample of the gum powder was placed on a piece of weighing paper. A few crystals of the gum powders were then placed in a thin walled capillary tube $10-15 \mathrm{~cm}$ long, $1 \mathrm{~mm}$ internal diameter, and closed at one end. The capillary, which contains the sample and the thermometer are then suspended so they can be heated slowly and evenly. The temperature at which the sample was observed to melt is taken as the melting point. This was performed for each of the gum Acacia and rubber latex sample (Zhong et al., 2009)

\section{Surface Tension by Contact Angle}

Droplets of the samples was placed on a flat surface and the angle between the surface and the droplet surface with respect to air was measured using a modular "CAM 200 - optical contact angle and surface tension meter" at different time intervals.

\section{Determination of Crude Protein}

$1 \mathrm{~g}$ of the gum samples was weighed and introduced into the bottom of 500ml kjeldahls flask (Pyrex). 20ml of concentrated sulfuric acid (98.9\%) was added and mixed gently by swirling up under tap water. $10 \mathrm{~g}$ of $\mathrm{NaSO}_{4}$ and $1 \mathrm{~g}$ of $\mathrm{CuSO}_{4}$ were mixed and $3 \mathrm{~g}$ of this was introduced into the flask. The mixture was boiled gently in the kjeldahls flask. The heater was turned off and the solution allowed cooling. The digest mixture was made up to the $100 \mathrm{ml}$ with distilled water in a $100 \mathrm{ml}$ volumetric flask. $10 \mathrm{ml}$ of $20 \%$ boric acid was measure out into $250 \mathrm{ml}$ beaker and four drops of the indicator was added. $10 \mathrm{ml}$ of the digest was placed in the distillation column flask. $30 \mathrm{ml}$ of $40 \% \mathrm{NaOH}$ was added to the $10 \mathrm{ml}$ of the digest slowly from the syringe. The heating system was switched on and continued for 25 minutes. The receiver beaker was removed and the distillate titrated with $0.1 \mathrm{~N}$ until end point. The reagents used were as-received without further purification.

$$
\% \text { Protein }=\underline{1.4 \times \text { D.F } \times 100 \times 6.25}
$$


Where;

$$
\text { Wt. of sample }
$$

$$
\begin{aligned}
& \text { Dilution factor }(\text { D.F })=\frac{100}{10}-\ldots \ldots \ldots-\ldots-\ldots \\
& \% \text { Protein }=\% \mathrm{~N} \text { x } 6.25
\end{aligned}
$$

\section{Percentage Lipid Determination}

This is done by the gravimetric method of AOAC. $5 \mathrm{~g}$ of the gum samples will be introduced into a clean dried $500 \mathrm{ml}$ round bottom flask (W1) and $300 \mathrm{ml}$ of petroleum ether $\left(40-60^{\circ} \mathrm{C}\right)$ for the extraction was poured into the flask fitted with Soxhlet extraction unit. The round bottom flask and a condenser were then connected to the Soxhlet extractor and cold-water circulation was switched on. The heating mantle was switched on and heating rate was adjusted until the solvent reflux at a steady rate. This process was carried out for 6 hours. The solvent was recovered and the oil dried in an oven at $70^{\circ} \mathrm{C}$ for 1 hour. the round bottom flask and oil were left to cool and then weighed (W2). The \% lipids content is calculated using the equation (7) as shown in Equation 7.

$$
\% \text { crude lipid content }=\frac{w 2-w 1}{w t . \text { of sample }} \times 100
$$

\section{Total Carbohydrate Content}

This measures the carbohydrate content and usually includes the fiber content of the samples. This conveniently is done by the difference method (Okore, 2009).

Total carbohydrate content $=100-(\%$ lipid $+\%$ moisture $+\%$ ash $+\%$ protein $)$

\section{Internal Energy}

The energy value was calculated by the factors of $4,9,4$. Here the value of the protein content was multiplied by 4 , that of lipid by 9 and that of total carbohydrate by 4 . The sum of these values was expressed in kcal/100g sample (Sharma, Chechani, \& Dhuldhoya, 2007; Yusuf, 2011). 


\section{Water Absorption}

This was performed following ASTM D570. The gum samples were dried in an oven for 6 hours at $125^{\circ} \mathrm{C}$ and then placed in a desiccator to cool. Immediately upon cooling the specimens were weighed. The materials were then immersed in water at $25^{\circ} \mathrm{C}$ for 10 hours. The specimens were removed and reweighed.

$$
\% \text { water absorption }=\frac{\text { wet weight }- \text { dry weight }}{\text { wet weight }} \times 100
$$

\section{Fourier Transform Infrared Spectroscopy (FTIR) Analysis}

FTIR is commonly used for qualitative identification of various functionalities; the FTIR spectrum of the gum samples was recorded with a Perkin Elmer RXI spectrophotometer. The gum samples were mixed with $\mathrm{KBr}$ (potassium bromine) and examined by infrared spectroscopy because these spectra are usually sensitive to chemical composition (Okore, 2009).

\section{RESULTS AND DISCUSSION \\ Physico-Chemical Properties}

Table 1 shows the physical state and result of proximate analysis of both samples for comparative purposes. While sample A looked brownish and odorless, sample B looked milky and had a smell close to that of rotten egg and characteristic of ammonia. This was corroborated by the result of the $\mathrm{pH}$ which revealed that it was alkaline (8.97) in nature (Table 1). The smell may be due to the preservation used for the latex after tapping and to keep it fresh in the liquid state. Both samples have similar ash content, density and carbohydrate and hence similarity in the internal energies (Idris, 2014). The low acidic content ( $\mathrm{pH}$ of 4.12) of the guar gum may be the presence of alkaline and alkaline-earth metals ( $\mathrm{Ca}, \mathrm{Mg}, \mathrm{K}, \mathrm{Na}$ and $\mathrm{Fe}$ ) that can form acidic salts.

Table 1: Physical State and Proximate Analysis of gum samples 


\begin{tabular}{|c|c|c|c|}
\hline S/N & Properties & Sample A (Guar gum) & Sample B (NRL) \\
\hline 1 & Color & Brownish & Milky \\
\hline 2 & Odor & Odorless & Rotten egg smell \\
\hline 3 & Density & $0.012 \mathrm{~g} / \mathrm{ml}$ & $0.009 \mathrm{~g} / \mathrm{ml}$ \\
\hline 4 & Moisture & $7.64 \%$ & $5.7 \%$ \\
\hline 5 & Ash & $6.9 \%$ & $7.3 \%$ \\
\hline 6 & $\mathrm{pH}$ & 4.20 & 8.97 \\
\hline 7 & Melting-point & $76^{\circ} \mathrm{C}$ & $91^{\circ} \mathrm{C}$ \\
\hline 8 & Water Adsorption & $86.58 \%$ & $14.53 \%$ \\
\hline 9 & Specific Gravity & 38.17 & 37.78 \\
\hline 10 & Nitrogen & $0.27 \%$ & $0.41 \%$ \\
\hline 11 & Protein & $1.69 \%$ & $2.56 \%$ \\
\hline 12 & Lipid & $1.2 \%$ & $1.8 \%$ \\
\hline 13 & Carbohydrate & $95.65 \%$ & $94.34 \%$ \\
\hline 14 & Internal Energy & $400.2 \mathrm{kcal} / 100 \mathrm{~g}$ & $403.8 \mathrm{kcal} / 100 \mathrm{~g}$ \\
\hline
\end{tabular}

Guar gum is observed to have a melting temperature of $76^{\circ} \mathrm{C}$ which is far less than the value $295^{\circ} \mathrm{C}$ reported by (Yusuf, 2011). This huge difference may be due to the level of D-galactose (heterogeneous nature) of the gum exudates, as gums of higher D-galactose have higher melting point (Zhong et al., 2009) . The water adsorption capacity of NRL sample was strikingly low (14.53\%) compared to guar gum (86.58\%). It also suggests the presence of more hydrophilic sites/pores in guar gum. While guar gum contains salts that are capable of forming hydrates, NRL contains isoprenes and other unsaturated hydrocarbons that have hydrophobic properties and hence are insoluble in water. This may suggest why it is used for water shielding purposes as well as in other non-food industries for the fabrication of plastics, automobile tires, balls etc. Guar gum on the other hand finds application even in food additives (Vaysee, L., Bonfils, \& Beve, 2009) as well as other applications because of its solubility in water (Abdulbari, Shabirin, \& Abdurrahman, 2014; A. I. Dosumu, Edomwonyi-Otu, Abubakar, \& Yusuf, 2019; I. A. Dosumu et al., 2020). The 
higher amount of nitrogen and protein (amines) in guar gum further lends credence to the obtained $\mathrm{pH}$ that suggests the presence of ammonia and possession of alkaline properties (Sukkatom et al., 2012).

\section{Effect of Shear Rate on Viscosity and Thixotropy}

The Figures 1 and 2 respectively gives the variation of viscosity and thixotropy of the gum samples under shear. For both samples, viscosity increases with shear rates howbeit in different proportion

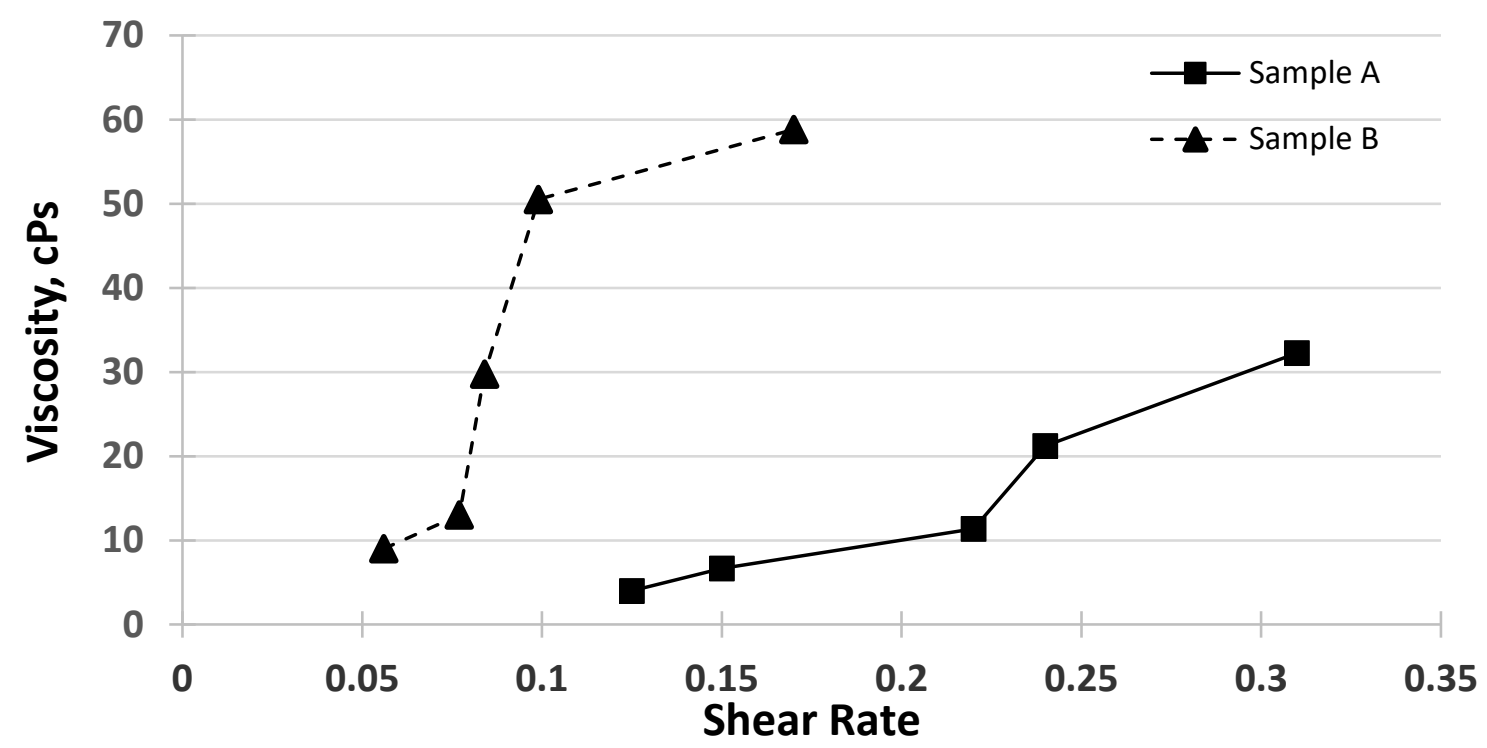

Figure 1: Viscosity vs Shear Rate for Gum Samples

The difference in the response of the viscosities to shear rate may be related to the D-galactose content. Both gums exhibited shear-thickening properties with NRL exhibiting higher shearthickening and rheopectic characteristics. Gum Arabic is seen to exhibit the property of a Bingham plastic and hence non-Newtonian due to its response to shear. The observations here slightly varies from those reported by Yusuf (Yusuf, 2011), and could be partly due to the D-galactose content. The viscosity of their solution is therefore influenced by the prevailing temperature (Sultan \& Al, 2013). 


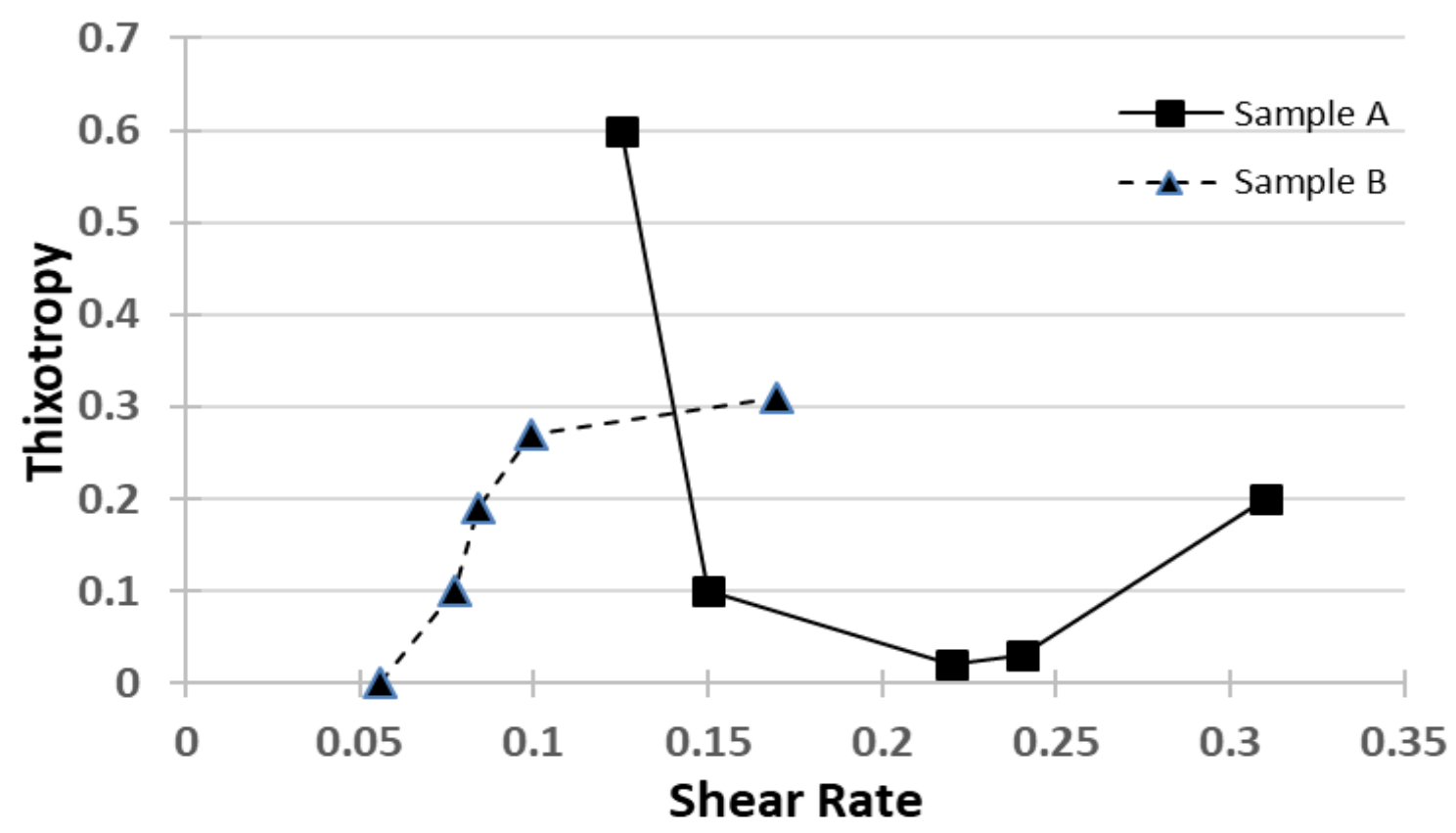

Figure 2: Thixotropy vs Shear Rate for Gum Samples

To further understand the response of the samples to stress, Figure 2 shows the plot of the response of thixotropic property. It can be observed that while Natural Rubber Latex (NRL) has good antithixotropic and rheopectic property, gum Arabic is thixotropic and will exhibit a change in the degree of thixotropy as shear rate is increased beyond a threshold. Hence gum Arabic can be described as possessing or exhibiting pseudo-plastic characteristics. The D-galactose content appear not to have direct influence on its thixotropic behavior. NRL on the other hand exhibit a stability at rest but when agitated it becomes fluidized with constant shear rate and viscosity increase (see Figure 1) and this observation corroborates previous reported investigation (Johns \& Rao, 2003).

\section{Wettability and Contact Angle}

Figure 3 shows the wettability of both samples over time. It can be deduced that NRL promotes better wettability because its contact angle decreases rapidly with time, hence its bonding strength is enhanced with increase in effective surface area. This may also explain why Cobblers spread their gums so thinly on surfaces that needs to be joined. This property of wettability may be related 
to their poor water absorption characteristics as discussed in Table 1. The excellent water absorption capacity of gum Arabic implies that its wettability will be less as shown in Figure 3. Despite displaying good bonding characteristics i.e., it does not wet a surface easily, targeted modifications of the material will have to be undertaken to enhance and maximize the material's bonding properties. However, this property makes it an excellent stabilizing agent in many beverages (norevo.de, 2017).

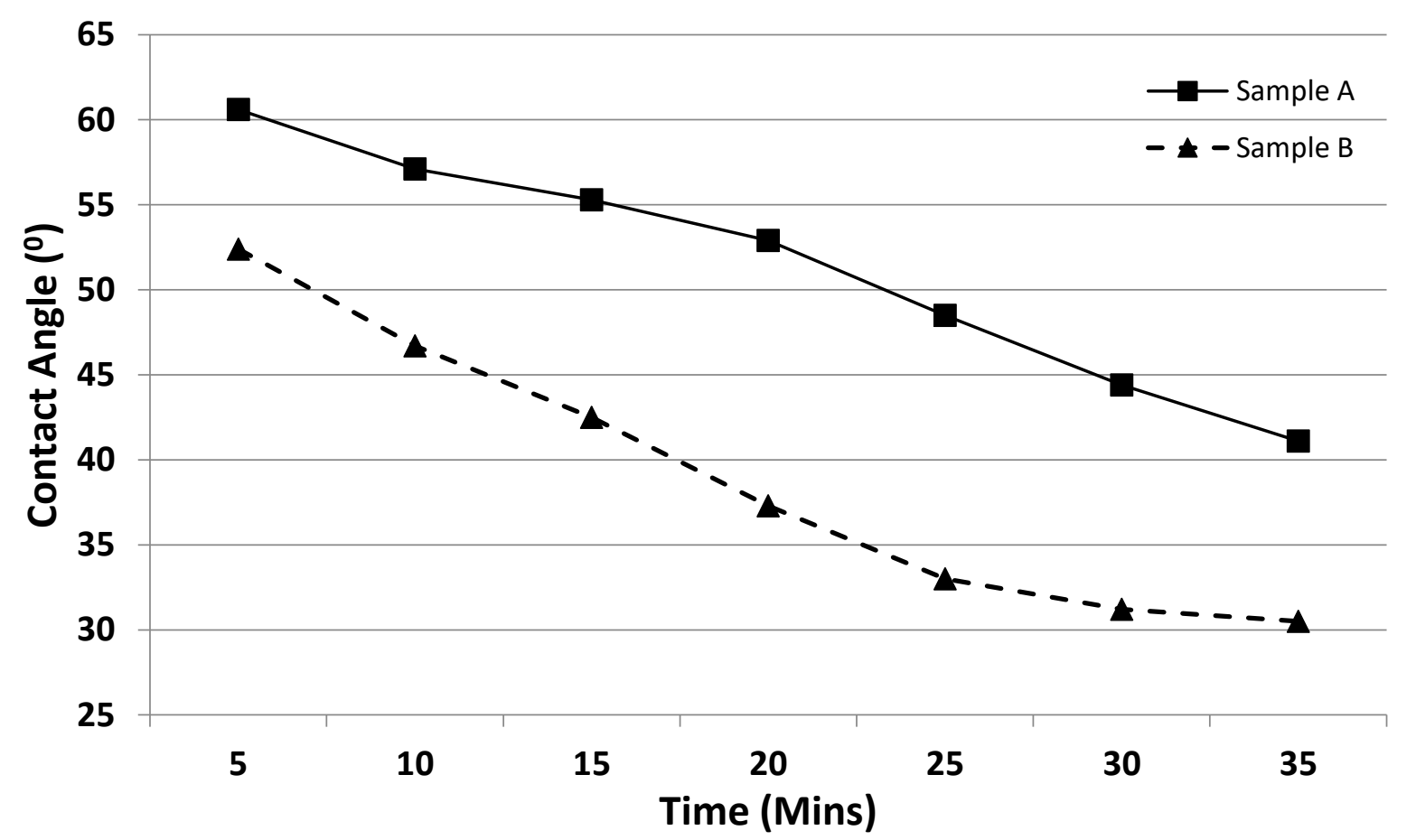

Figure 3: Variation of contact angle with time for gum samples

\section{FTIR Spectra}

Figures 4 and 5 displays the frequency shifts for gum Arabic and NRL respectively. The determination of the different functional groups and peaks in the spectra of the gums was with the help of an infrared spectroscopy (IR) absorption table REF) 


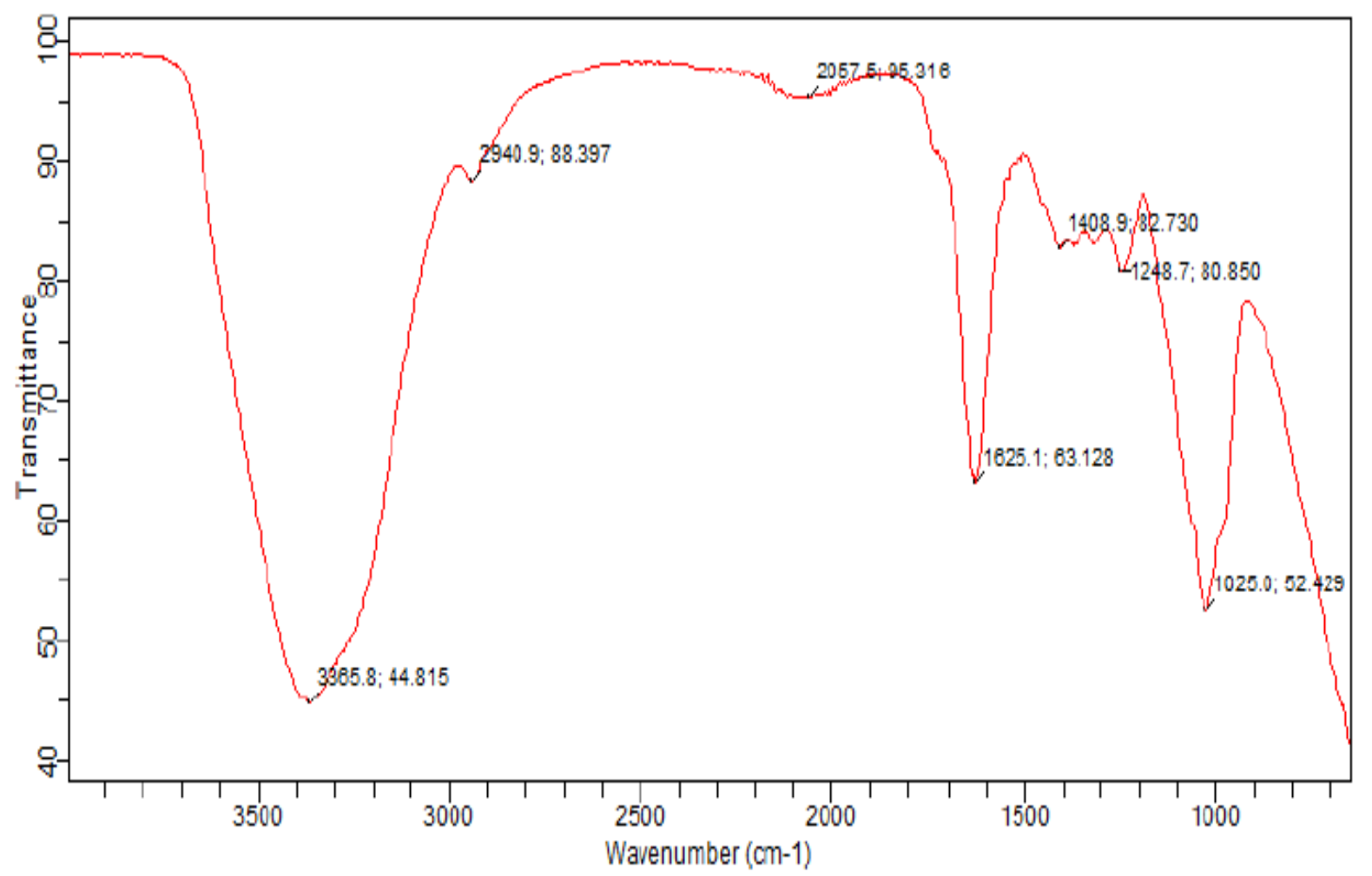

Figure 4: FTIR spectra for Gum Arabic

Gum Arabic polyisoprene peaks were observed at wave numbers, $3365.8 \mathrm{~cm}^{-1}$ and it denotes the presence and strong intensity of alcoholic compounds $\left(\mathrm{C}=\mathrm{C}-\mathrm{CH}_{2}-\mathrm{OH}\right)$ while the peaks at 2940.9 $\mathrm{cm}^{-1}$ is representative of carboxylic acid $(\mathrm{R}-\mathrm{C}(\mathrm{O})-\mathrm{OH})$. The medium intensity peaks at 1625.1 $\mathrm{cm}^{-1}$ belongs to amide group $\left(\mathrm{R}-\mathrm{C}(\mathrm{O})-\mathrm{NH}_{2}\right)$ while bends of alkyl group $\left(-\mathrm{CH}\left(\mathrm{CH}_{3}\right)_{2}\right.$ are shown with medium intensity at $1408.9 \mathrm{~cm}^{-1}$ and $1248.7 \mathrm{~cm}^{-1}$. A stretch of strong intensity peak of the alkyl halide group was observed at $1025.0 \mathrm{~cm}^{-1}$. These values are within the ranges reported by Yusuf (Yusuf, 2011) who characterized Acacia Senegal (Dakwara), Acacia sieberiana (Farar kaya) and Acacia nilotica (Bagaruwa). The differences in the location of the functional groups may be related to tree origin and duration of harvest of the gum crystals. The presence of strong peaks of the alcoholic compounds, carboxylic acid and Alkyl halide may further explain the degree of solubility and water absorption capacity and wettability of gum Arabic. 


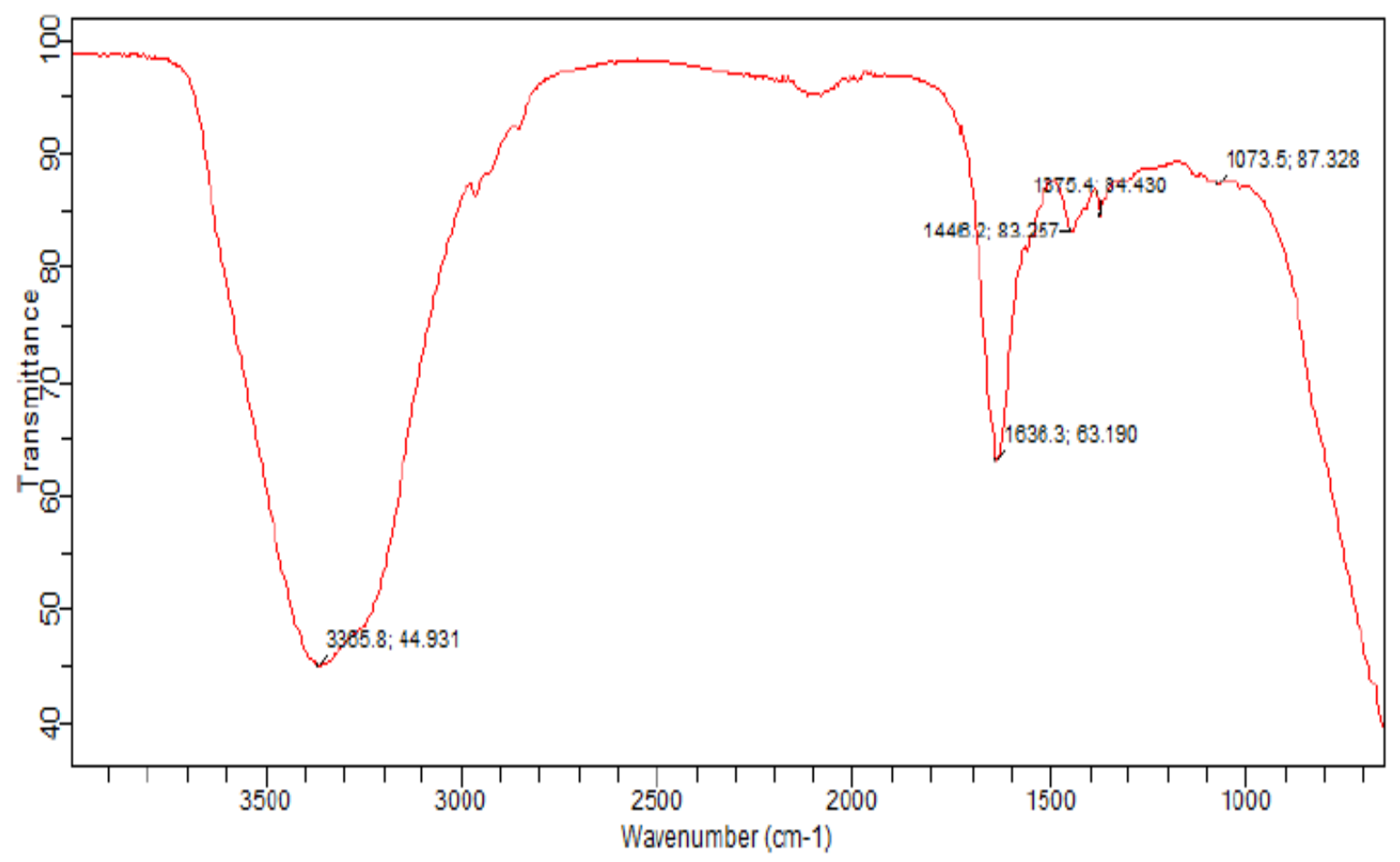

Figure 5: FTIR spectra for Natural Rubber Latex Gum

In the NRL spectra (Figure 5), weak intensity Amine group (RR 'N-H) was observed at 3665.8 $\mathrm{cm}^{-1}$, while the presence of Amide (R-C (O) -NR'R") of strong intensity was seen at $1636.3 \mathrm{~cm}^{-1}$. At $1446.2 \mathrm{~cm}^{-1}$, alkyl $\left(\mathrm{CH}_{2}\right)_{\mathrm{n}}$ bend of medium intensity was present and nitro-compounds $\left(\mathrm{R}-\mathrm{NO}_{2}\right)$ at $1375.4 \mathrm{~cm}^{-1}$ with medium intensity, as well as strong intensity peaks of Ethers (Ar-O-R) at $1073.5 \mathrm{~cm}^{-1}$. and it is close in agreement with that reported (Johns \& Rao, 2003)

\section{CONCLUSION}

The following can be concluded from the results obtained from the study;

- Gum samples have high densities with corresponding thermally stability.

- Both gums are carbohydrates by composition with high internal energy content. 
- The viscosity of both samples increases with shear rate with gum Arabic displaying thixotropic and pseudo-plastic properties and NRL noted be anti-thixotropic and rheopectic.

- The moisture absorption, contact angle and FTIR analyses of both gum samples gave valuable insight into their hydroscopic nature.

- FTIR was shown to be a useful technique to discern the functional groups present in any organic material.

\section{REFERENCES}

Abdallah, M. N., Edomwonyi-Otu, L. C., Yusuf, N., \& Baba, A. (2019). Aloe Vera Mucilage as Drag Reducing Agent in Oil-Water Flows. Arid Zone Journal of Engineering, Technology \& Environment, 15(2), 248-258.

Abdulbari, H. A., Shabirin, A., \& Abdurrahman, H. N. (2014). Bio-polymers for improving liquid flow in pipelines-A review and future work opportunities. Journal of Industrail Engineering Chemistry, 20(4), 1157-1170. https://doi.org/10.1016/j.jiec.2013.07.050

Dosumu, A. I., Edomwonyi-Otu, L. C., Abubakar, A., \& Yusuf, N. (2019). Drag Reduction Performance of Natural Gums in Oil-Water Flow through Pipes of Different Diameters. Nigerian Research Journal of Engineering and Environmental Sciences (RJEES), 4(1), 17-26.

Dosumu, I. A., Edomwonyi-Otu, L. C., Yusuf, N., \& Abubakar, A. (2020). Guar Gum as Flow Improver in Single-Phase Water and Liquid - Liquid Flows. Arabian Journal for Science and Engineering, 45, 1-7. https://doi.org/10.1007/s13369-020-04429-2

Edomwonyi-Otu, L. C. (2019). Distortion of velocity profiles of water flow with heavy molecular weight polymers. Transfer Phenomenon in Fluid and Heat Flows VII in: Journal of Defect and Diffusion Forum (DDF), 392, 228-238.

Edomwonyi-Otu, L. C., \& Aderemi, B. O. (2010). Alums from Kankara Kaolin. Nigerian Journal of Engineering (NJE), 2, 38-44.

Edomwonyi-Otu, L. C., Aderemi, B. O., Ahmed, A. S., Coville, N. J., \& Maaza, M. (2013). Application of Alum From Kankara Kaolinite in Catalysis: A Preliminary Report. In Processing and Properties of Advanced Ceramics and Composites V (Vol. 240). https://doi.org/10.1002/9781118744109.ch19

Edomwonyi-Otu, L. C., Chinaud, M., \& Angeli, P. (2015). Effect of drag reducing polymer on horizontal liquid-liquid flows. Experimental Thermal and Fluid Science, 64, 164-174. https://doi.org/10.1016/j.expthermflusci.2015.02.018 
Gimba, M. M., \& Edomwonyi-Otu, L. C. (2020). Drag Reduction with Polymer Mixtures In OilWater Flows : Effect of Synergy. Journal of the Turkish Chemical Society B: Chemical Engineering, 3(1), 1-8.

Hassan, A. A., \& Singh, M. (2014). Biological Extracts for Preservation of Natural Rubber Latex. MRB Rubber Technology Developments, 14(February), 3-8.

Idris, S. A. (2014). Effect of Gum Arabic on the Structure Property Relationship. Ahmadu Bello University, Zaria, Nigeria.

Johns, J., \& Rao, V. (2003). Characterization of Natural Rubber Latex. Mangalore University, Mangalagangoln, India.

Okore, V. C. (2009). Grossly Unexploited Carriers or Adjuncts in Drug Delivery Systems. In African Tropical Plant Gums (pp. 7-26). Enugu.

Reichman, D. (1993). Hydrocolloids as Food Emulsifiers and Stabilizers (Vol. 12, pp. 411-426). Vol. 12, pp. 411-426. Chicago.

Sharma, B. R., Chechani, V., \& Dhuldhoya, N. . (2007). Guar Gum. Lucid Colloids Limited, 1-13.

Sultan, M., \& Al, E. T. (2013). Genetic diversity of guar. Parkistan Journal of Agric-Biotechnology and Genetic Resource, 45(3), 865-870.

Taha, K. K., Elmahi, R. H., Hassan, E. A., Ahmed, S. E., \& Shyoub, M. H. (2012). Analytical Study On Three Types Of Gum From Sudan. Journal of Forest Products \& Industries, 1(1), 11-16.

Vaysee, L., Bonfils, F., \& Beve, J. S. (2009). Characterization of Natural Rubber Latex. Research Thesis on Natural Rubber. lowa State University, lowa, USA.

Yusuf, A. K. (2011). Studies on some physicochemical properties of the plant gum exudates: Acacia senegal (DAKWARA), Acacia sieberiana (FARAR KAYA) and Acacia nilotica (BAGARUWA). Journal of Research in National Development, 9(2), 10-17.

Zhong, J. P., Peng, L. C., Si-Dong, L., Ling-Xue, K., Lei, Y., Shuang-Quan, L., \& Xiao-Dong, S. (2009). Study on properties of Natural Rubber during maturation. Journal of Polymer Materials, 26(3), 351-360. 